\title{
Evaluation of the Contribution of Oil Revenue on Economic Development in Nigeria
}

\author{
Joseph Ugochukwu Madugba ${ }^{1}$, Michael Chidiebere Ekwe ${ }^{1} \&$ Stella Ogechukwu Okezie ${ }^{1}$ \\ ${ }^{1}$ Department of Accounting, College of Management Sciences, Michael Okpara University of Agriculture, \\ Umudike, Umuahia, Nigeria \\ Correspondence: Joseph Ugochukwu Madugba, Department of Accounting, College of Management Sciences, \\ Michael Okpara University of Agriculture, Umudike, Umuahia, Nigeria. Tel: 234-806-369-7038. E-mail: \\ joeugochukwu@yahoo.com, joeugochukwu014@gmail.com
}

Received: March 8, 2016

doi:10.5539/ijef.v8n6p210
Accepted: March 18, 2016

Online Published: May 25, 2016

URL: http://dx.doi.org/10.5539/ijef.v8n6p210

\begin{abstract}
The study evaluation of the contributions of oil revenue on economic development in Nigeria tested the impact of growth rate in oil revenue and growth rate in Gross Domestic product and growth rate in total federally collected revenue of the Government from 1991 to 2012. Regression analysis was used to carry out data analysis with the aid of SPSS version 20. Results showed that a unit change in growth rate of oil revenue will lead to an equal unit change in growth rate of gross domestic product. The study recommends that federal government should intensify efforts to increase revenue derived from oil especially as it impacts on GDP and federally collected revenue.
\end{abstract}

Keywords: oil revenue, economic development, gross domestic product, total federal revenue

\section{Introduction}

Oil revenue refers to the income earned from the sales of crude oil. Since the discovery of oil in 1958 it has been the major source of government revenue in Nigeria accounting for about $90 \%$ of total exports, an approximately of $80 \%$ of total government revenue. Nigeria has the world's tenth largest proven reserves $3.1 \%$ of global reserves) and is among the top ten oil producers in the world. The Nigeria oil sectors have since the discovery of oil played a crucial and dominant role in the Nigerian economy in 1958, in 1966 and 1967, there was a reduction in oil production as a result of the outbreak of civil war in Nigeria. In 1970, production increased. Between 1986 and 1987 the total oil production was 383.3 million barrels. In 1990s, the production increased again from 388.3 million barrels to 711.3, and in 1996 it rose to 7423 million barrels and 772.9 million barrels in 1998. Since then, the trend has continued from 1970 till date, there had been no year when proportion of crude oil exports in total export earnings fails below $91 \%$. In 2006, the Nigerian government estimated that earnings from oil sector amounted to N36billion each year (Asume, 2007).

The Nigerian oil sector can be divided or classified into three major sectors, that is upstream, downstream and gas. The upstream activities comprises of the aggregate work of exploration development and production of oil and gas products. Downstream activities refers to those activities that takes place from receipt of crude oil into crude oil tanks or gas into petrochemical tanks to the transportation of refined products to the final user or of processed products to the final user or if processed products to secondary industries (Wilsonet al., 2012).

The most concern of these sectors has been the downstream subsector which has connection or linkage with the final consumer since it is the distribution, arm of the oil industry. In 2003 due to unending crisis experienced in the downstream sector the federal government of Nigeria deregulated it for effectiveness.

\subsection{Statement of the Problem}

In the early 1950's, some development economist have suggested that natural resources abundances would help the backward states to rise above their capital short falls and provide revenue for their government to offer public goods and lift citizens out of their despairs poverty. In recent years $95 \%$ of government revenue and $99 \%$ of total export are dependent on oil. Expert thought the "black gold" would guarantee sustainable economic development. However, their expectations are far more restrained as Nigeria still has a slower than expected economic growth, poor economic diversifications, dismal social welfare indicators, devastating environmental impacts, high 
poverty levels and inequality, rampant corruption, high incidence of conflict and exceptionably poor governance. Natural resources availability and any consequent boom should relax the three traditional constraints of economic development that is fiscal revenues, domestic savings and foreign exchange (Gelb et al., 1998). In Nigeria the case is different but has resulted to the economy being over dependent on oil and has accounted for slow growth (Sachs \& Warner, 1995b). Increased inequality and poverty for a large majority of a country's population (Ross, 2005). The discovery of oil and its boom has made the Nigerian economy very mono-cultural and unsustainable given the depletible nature of oil and its price volatile and has made the economy vulnerable to external shocks and subject its development to multiple "fractures" (Ogunleye, 2008).

The boom and bust cycles experiences of Nigeria in the world oil market has also manifested itself through over valuation of Nigerian Currency which is responsible for high increases in the prices of non tradable goods and services, thus hurting the rest of tradable goods sector. Suffice to say exporting oil by itself does not transform poor countries into flourishing economics. Hence, there is increased need to find out if oil revenue has contributed positively or otherwise to Nigerian economy. This study is designed to fulfill this purpose among other things.

\subsection{Objective of the Study}

The major objective of this study is to examine the impact of oil revenue on economic development with the following specific objectives.

1) To examine the impact of growth rate in oil revenue on growth rate of gross domestic product in Nigeria.

2) To examine the impact of growth rate in oil revenue on growth rate of consolidated revenue of federal government.

\subsection{Research Questions}

i. What is the impact of growth rate in oil revenue on growth rate of Gross Domestic product in Nigeria?

ii. What is the impact of growth rate in oil revenue on growth rate federal government consolidation revenue?

\subsection{Statement of Hypothesis}

Ho1: There is no significant impact between growth rate in oil revenue and growth rate in Gross Domestic Product.

Ho2: There is no significant impact between growth rate in oil revenue and growth rate in Federal Government consolidated revenue.

\section{Literatures Review}

The search for oil in the country dates back to 1937 when a license was granted to Shell'd Arcy Company Limited which later metamorphosed into shell BP Petroleum Development Company of Nigeria Limited. (Okpe, 2003). In 1956, oil was discovered in commercial or exportable quantity in Oloibiri, Soku and Afam in the then Rivers State now in Rivers and Bayelsa States of the Niger Delta in Nigeria. The highest production per day as at then was 5100bpd hence; Nigeria joined the oil producing nations of the world.

The end of civil war in 1970 made way for Nigeria to join the rest of the oil producing nations to enjoy the boom in the world oil market. In 1971 she joined the Organization of Petroleum Exporting Countries (OPEC) and established the Nigerian National Petroleum Company (NNPC) in 1977 owned and controlled by Nigerian Government and which became a major player both in the upstream and downstream sector (Blair, 1976).

Nigeria is heavily and abundantly blessed in natural resources as this can be evidence in the country. Mainly, for the past five decades, the oil sector of the economy has been on the increase as it is evidence with export of crude oil. For instance, as oil production increased from 390.5 barrels in 1987 to 675.3 barrels in 1998, the export and revenue also increased. 1970 oil revenue amounted to N166.6million. But it increase to N1,591, 675.00 million in 2000 and N6,530, 3000 million in 2008. But this huge revenue from oil sector has made the economy highly oil dependent and complicated macroeconomic management (Anthony, 2012).

\subsection{Oil Revenue and Its Distribution in Nigeria}

The place of oil in the mind of average Nigerian has become more profound since the deregulation of the downstream segment of the Nigerian Oil Industry in 2003 (Gbadebo, 2008).

Presently Nigeria has four refineries with total capacity of 445,000 barrels per day (bpd) as: 


\begin{tabular}{cccc}
\hline Location & Date of establishment & Capacity installed (bpd) & Upgrade (bpd) \\
\hline i) & 1965 & 35,000 & 60,000 \\
Port Harcourt & 1978 & 100,000 & 125,000 \\
ii) Warri & 1980 & 100,000 & 110,000 \\
iii) Kaduna & 1989 & 150,000 & 150,000 \\
\hline iv) Port Harcourt & & & $\mathbf{4 4 5 , 0 0 0}$ bpd \\
\hline
\end{tabular}

The domestic consumption of Premium Motor Spirit (PMS) is 33million litres per day and the combined productive ability of the refineries in 445000 bpd if they are put to full capacity utilization, note that it was due to persistent shortage in supply that necessitated the deregulation of the downstream oil sub-sector.

In Nigeria, the price per litre of fuel influences greatly the price of other commodities, as it is evidence that an increase in price per litre of gasoline (PMS) will certainly lead to increase in prices of other commodities hence since the era of the civilian administration that has witnessed incessant increase in prices of premium motor spirit, the CBN has been battling with measures to keep liquidity in check in order to ensure that it does not increase adverse effects on the three key macroeconomic prices thus interest rate, inflation rate and exchange rates. Nigerian operates a federal system of government having three tiers namely federal, state and local governments. The constitution of the country at present vested ownership of land and petroleum resources on the federal government, hence, all oil, gas and tax revenues accruing from these resources are paid to the Federal government. However, the federal government transfers some petroleum revenue to the 36 states and 774 local government councils in the country. $13 \%$ of the Petroleum revenue is paid to oil producing states as derivation fund though it has been a source of controversy and tension between federal and state governments. However, from the federation account into which oil and gas revenues are paid, revenues between the tiers of governments are distributed as follows:

Federal government 52.68 percent

State government 26.72 percent

Local government 20.60 percent

\subsubsection{Contributions of Oil Industry}

\subsubsection{Employment Opportunity}

Provision of employment opportunities was the first contribution oil industry made to the economy as Nigerians were engaged then in drilling site clearing, transportation of materials and equipment, building of staff quarters and of course recreational facilities.

In this modern era, Nigerians are now employed in administrative position supervisory and managerial functions (Gbadebo, 2008).

\section{- Increase in Government Revenue}

It is evident that before the discovery of oil, Agriculture was the mainstay of Nigerian economy, but upon its discovery, diversion occurred because government earn more revenue, foreign exchange, and it attract more Foreign Direct Investment (FDI) then agriculture, this was made possible through increased crude oil production, increase in oil prices and more favourable fiscal arrangement obtained by the government as a result of its improved bargaining position over the years (Gbadebo, 2007; Anthony, 2012; Asume, 2007).

\section{- Major Source of Energy}

Petroleum remains the major and cheapest sources of energy in the country. The availability of huge reserves of natural gas provides a good opportunity for the supply of cheap energy to both industries and companies. Currently, natural gas and crude oil is jointly produced by and supplied by shell to Power Holding Company of Nigeria Plc for thermal electricity generation. It is also used for petroleum refining by Nigeria Petroleum Refining Company and other industries within the oil operations. Also, the domestic uses of petroleum products (petrol, kerosene, Diesel) cannot be over looked.

\section{- Improved Standard of Living}

The oil industry through the provision of employment, increased per capital income and development of basic infrastructural facilities has helped to positively improve the standard of living of Nigerian.

- Establishment of Oil Related Industries 
Also, other oil related industries have been established in the country because of the existence of oil companies brought about by crude oil for instance petrochemical. Industries.

\section{- Existence of Wide Range of Products}

Other revenge of products like paints, insecticide, tiles, fertilizers etc. have come into existence in the country and its production made easy since crude oil and products are used in their production.

\section{- Foreign Exchange}

This is a set of explicit objectives with regard to the world beyond the borders of a given social unit and a set of strategies and fabrics designed to achieve those objects. Oil industry has enhanced Nigerian foreign exchange through exportation of crude oil; substantial revenue accrues to the country and makes her to be in a healthy position of being capable of financing her development programmes.

\subsubsection{Gross Domestic Product: (GDP)}

"GDP at purchaser's price is the sum of gross value added by all resident producers in the economy plus any product taxes and minus any subsidiaries not included in the value of the products, it is calculated without making deductions for depreciation of fabricated assets or for depletion and degradation of natural resources (World Bank Report, 2011).

According to Central Bank of Nigeria (2010) GDP is the value of goods and services produced in an economy during a period of time irrespective of the nationality of the people who produced the goods and services. It is usually calculated without making any allowance for capital consumption (or deductions for depreciation) GDP and per capital income can be used to assess the growth rate of a country (Schiller, 2003). Developing and underdeveloped countries' GDP growth and population growth are always different. Population grows at a slow rate in developing countries and hence their per capital income and gross deposit products are always high and easily achieved.

In underdeveloped countries, population growth is very rapid making it difficult to raise standard of living (Schiller, 2003). Between 1990 to 2000 Nigeria experienced averaged economic growth rate. The GDP was 2.4, national income of 1.121, while population of 2.8 and with a per capital income of - 0.4 (World Bank Development Report, 2002; Schiller, 2003; Ogbonna et al., 2012).

\subsubsection{Consolidated Revenue}

According to Livingstone (2004) consolidated revenue in the fund into which shall be paid all receipts belonging exclusively and accruing to the government from the general taxing and revenue powers of government.

According to Central Bank of Nigeria statistical bulletin, the total federally collected revenue in 1981 was N13,290.50 million while oil revenue for the same year amounted to N8564.10million, thus contributing about $64 \%$ of the total consolidated revenue of the government. In 1991, the total federally collected revenue was $100,991.60$ million while oil revenue was $82,666.40$ million accounting for $82 \%$ of the total revenue of the government. 2001 was not exceptional as total federally collected revenue amount to 2,231,600.00 million and oil revenue was $1,707,562.80$ contributing about $77 \%$ of consolidated revenue of the government. Suffice it to say that oil is the dominant source of government revenue (Budina \& Van Wijnbergen, 2008). Nigerian economy has the potentialities of becoming one of the twenty leading economies of the world before the year 2020 if their abundant crude oil wealth, human and natural resources are properly managed and corruption mitigated (Nafziger, 2006; Ibadam, 2005).

According to Binda et al (2008) Nigeria gained an extra \$390billion in oil-related fiscal revenue between 1970 and 2005 or 4.5times 2005 Gross Domestic Product (GDP). Bawa and Mohammed (2007) opined that Nigeria with all its oil wealth has performed poorly with GDP, per capital income today not higher than at independence in 196

\subsection{Theoretical Framework}

Economists have expressed a lot of opinion regarding economic growth and developments. Many economic theories are of the opinion that natural resource income of a nation impact positively on economic growth and development (Yakubu, 2008; Harrod, 1939; Domar, 1946). This study will consider the export instability theory.

\subsubsection{Export Instability Theory}

This theory opined that exports of developing countries are more concentrated than those of developed countries and is made up of largely primarily agricultural and mineral commodities. Mineral deposits are price - inelastic growth in demand and supply, with demand very sensitive to economic activity in consuming regions. Cyclical 
demand fluctuations then induce large price and revenue strife's. Terms of trade variations, tends to be larger for developing countries than for developed countries and scholars suggest mineral exports are prone to wider fluctuations in export prices and revenues than other developing countries.

This theory will be adopted in this study because its focus is on the subject matter- mineral exports of developing countries to developed countries and our major export product in Nigeria is crude oil which its contribution to economic development is the major concern of this study.

\subsection{Empirical Review}

In 2007, Moradi investigated the effects of oil resource abundance on economic growth and income distribution in Iran. The challenge was to find out if oil resource abundance impact positively on economic growth and income distribution in Iran. The study covered a period of 37 years, which spans from 1968-2005. The result of the study indicated a positive and significant effect of oil abundance on GDP but the value of the estimated coefficient was too small, and he concluded that oil abundance is not a blessing for Iran.

Odulani (2007) carried out a research on crude oil and the Nigerian Economic performance. The challenge of the study was to find out the relationship between the crude oil sector and the Nigerian economic performance. The study employed ordinary least square regression method. The study covered a period of 35 years that is 1970-2005. The data for analysis was gotten from Central Bank of Nigeria Statistical Bulletin of various years. The findings of the study were that crude oil consumption and export have contributed to the improvement of the Nigerian economy. The study therefore recommends that government should implement policies that would encourage the private sector to participate actively in the crude oil sector. Also, security should be boosted on the high sea where crude oil products are being smuggled as it will help to reduce the loss from illegal export of crude oil products.

Ogbonna et al. (2012) investigated Petroleum Income and Nigerian Economy: Empirical Evidence. The study covered a period of nine years from 2000-2009. The focus of the study was to identify the effects of petroleum income on Nigerian Economy. The sample of the study covered all economic sectors of the country, including the oil sector and non oil sector. The data for analysis was gotten from Central Bank of Nigeria Statistical Bulletin, Nigerian National Bureau of Statistics and the Nigerian National Petroleum Corporation. The data collected was analyzed using the simple regression with the aid of SPSS. The result indicated that oil revenue has a positive and significant relationship with GDP and PCI, but a positive and insignificant relationship with INF. Also Petroleum Profit Tax Revenue has a positive and significant relationship with GDP and PCI, but a negative and insignificant relationship with inflation. It was also found that LF has a positive but insignificant relationship between GDP, PCI and INF respectively. The study therefore, concludes that Petroleum Income has positively and significantly impact on the Nigerian economy when measured by GDP and PCI for the period 2000-2009.

In the empirical literature, there exist studies on the impact of oil revenue on economic development in Nigeria. However, there has not been a recent work covering the period 1991-2014 and more so, none of the empirical literatures have considered the growth rate of oil revenue on growth rate of Gross Domestic Product as well as growth rate of Total Federally Collected Revenue in Nigeria. These gaps necessiate the study of this nature

\section{Materials/Methods}

The sample for this study is the national economy of Nigeria, which covers all the economic sectors of the country, including the oil sector and non oil sector. The data used for this study is secondary data sourced from Central Bank of Nigeria statistical bulletins covering from 1991 to 2012 with aim to ascertain the contribution of oil revenue to economic develop in Nigeria.

\subsection{Model Specification}

To attain the purpose of this study, the following functional and explicit models were formulated:

$$
\begin{aligned}
& \text { Growth Rate }=\frac{\text { current year }}{\text { Previous year }} \times \frac{100}{1} \\
& \text { GR }=\frac{\text { Rcy }}{\mathrm{RPY}} \times \frac{100}{1} \\
& \mathrm{G}_{\mathrm{R}} \mathrm{G}_{\mathrm{REV}}=\mathrm{F}(\mathrm{OR}) \\
& \mathrm{G}_{\mathrm{R}} \mathrm{G}_{\mathrm{REV}}=\mathrm{F}(\mathrm{OR}) \\
& \mathrm{G}_{\mathrm{R}} \mathrm{G}_{\mathrm{REV}}=\mathrm{BO}+\mathrm{B}_{1} \mathrm{OR}+\mathrm{U}
\end{aligned}
$$




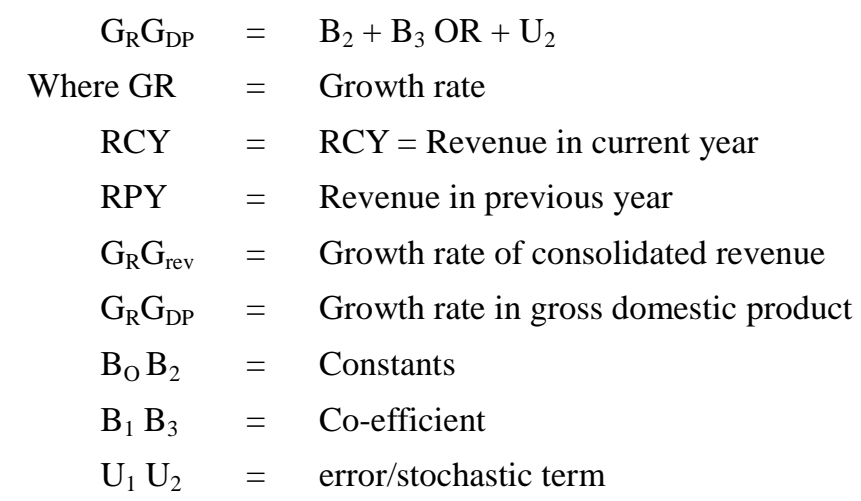

\section{Discussion of Findings}

$\mathrm{Ho}_{1}$ : There is no significant impact between growth rate in oil revenue and growth rate in Gross Domestic Product.

\begin{tabular}{llccccc}
\hline \multicolumn{7}{c}{ Co-efficient A } \\
\hline \multicolumn{7}{c}{ Unstandized co-efficient } \\
\hline \multicolumn{1}{l}{ Model } & B & Std Error & Beta & t & Standized co-efficient \\
\hline 1 & (constant) & 8610 & 65.861 & & .131 & .897 \\
& GRoR & 1.808 & 1.033 & 373 & 1.751 & .096 \\
\hline
\end{tabular}

a. Dependent Variable: GRGDP.

\begin{tabular}{cccccc}
\hline \multicolumn{6}{c}{ Model Summary B } \\
\hline Model & R & R-Square & AdjustedR Square & Std. Erro of the estimate & Durbin Waston \\
\hline 1 & .3739 & .139 & .094 & 242.40610 & 2.257 \\
\hline
\end{tabular}

a. Predicators (constant) GRoR.

b. Dependent variable GRGDP.

Source: Researcher's Estimation, 2015 (see Spcs Appendix 2 \& 3).

The regression results of the impact of growth rate of oil revenue on growth rate of gross domestic product. It can be seen from the table above that the co-efficient of regression (B).

Indicate that the relationship between growth rate in gross domestic product and the growth rate in oil revenue is positive at 1.808. The impaction of this sign is that the dependent variable growth rate in gross domestic product GRGDP is positively influenced by growth rate in oil revenue, implying that for every unit increase in oil revenue, GDP is also predicative to increase by 1.808 units.

The co-efficient of correlation $\mathrm{R}$ gave a value of .373 implying that the strength of the relation between growth rate in Oil Revenue and growth rate in GDP is weak at $37.7 \%$. Furthermore, the co-efficient of determination $\mathrm{R}^{2}$ of 0.139 indicate that growth rate in oil revenue can only explain $13.9 \%$ of the variations in GDP growth.

Finally, the computed t-statistic for the co-efficient of oil revenue growth rate in 1.751 which is lower than the critical statistics of 2.086 (a) 0.05 level of significance and 20DF. This means that the null hypothesis is not rejected. Hence, we conclude that growth rate in Gross Domestic Product.

$\mathrm{Ho}_{2}$ : There is no significant impact between growth rate in oil revenue and growth rate in Total Federally Collected Revenue.

\begin{tabular}{llllll}
\hline \multicolumn{5}{c}{ Co-efficient A } \\
\hline Model & Bnstandized co-efficient & standized co-efficient \\
\hline 1 (constant) & 4.523 & Std Error & Beta & t & sig. \\
GRoR & .663 & 8.008 & & .565 & .579 \\
\hline
\end{tabular}

a. Dependent Variable: GRTFCR. 


\begin{tabular}{llllll}
\hline \multicolumn{5}{c}{ Model Summary B } \\
\hline Model & R & R-Square & Adjusted R Square & Std. Error of the estimate & Durbin Waston \\
\hline 1 & $.771^{\mathrm{a}}$ & .595 & .573 & 29.47375 & 1.833 \\
\hline
\end{tabular}

a. Predicators (constant) GRoR.

b. Dependent variable GRTFCR.

Source: Researcher's Estimation, 2015 (see Appendix 4).

From the table above, it can be variable that the co-efficient of regression (B) indicates that the relationship between Growth Rate in total federally collected revenue and growth rate in oil revenue is positive at 0.663 implying or showing that for every one unit increase in oil revenue, total federally collected revenue is also predicted to increase by 0663 units.

The co-efficient of correlation $\mathrm{R}$ gave a value of .771 implying that the strength of relation between growth rate in oil Revenue and growth Hall in Total federal collected revenue is $77.10 \%$. Furthermore, the co-efficient of determination $\mathrm{R}^{2}$ of 0.595 indicates that growth rate in oil revenue can explain about $59.5 \%$ of the variations in total federally collected Revenue.

Finally, the computed t-statistic for the co-efficient of oil revenue growth rate is 5.281 which is greater than the critical t-statistic of 2.086 (a) 0.05 level of significance and 20pF. This means that the bull hypothesis is rejected. Hence, we conclude that growth rate in Oil Revenue does significantly impact on growth rate in total federally collected Revenue.

\section{Conclusion and Recommendations}

One of the hypothesis tested in this study revealed that growth rate in oil revenue has no significant impact on growth rate in gross domestic product, while hypothesis two showed that there is a significant not part between growth rate in oil revenue and growth rate in total federally collected revenue. However, the two estimated co-efficient of the two models is positively signed, the study therefore conclude that growth rate in oil revenue significantly impact on both growth rate in gross domestic product and in growth rate in total federally collected revenue.

From the conclusion above, it is expedient and inevitable for the following policy recommendations to be made:

- Multinational Oil Companies: Government should as a matter of urgency ensure that all multinational oil companies are deeply involved in corporate social responsibility mostly to their host communities as it will help to reduce unhealthy atmosphere for their exploration activities.

- Host Communities: Government should intensify efforts to arrest the social unrest in the host communities since such unhealthy atmosphere affects negatively exploration.

- Security: Government loses a lot of crude oil from the activities of smugglers mainly in the high sea,. Therefore, security should be boosted to stop such unwholesome lost here improve exportation of crude oil.

- Diversification: Also, government should diversify our economy and invest in order sectors as to boost revenue from such sectors as they will serve as backbones to the economy in the days of reduction in oil prices.

- Corruption: Government should establish and maintain more corruption fighting bodies to minimize the rate at which public office holders' loot public funds.

\section{References}

Adams, G. A. (1989). Investment opportunities in the oil and gas industry in Nigeria. NNPC, 10(2).

Asume, I. O. (2007). Oil and Gas Revenue and development challenges for the Niger Delta and Nigeria. Paper presented at the expert Group meeting on the use of Non-Renewable Resources Revenues for sustainable Local Government organized by the UN Department of Economics and Social Affairs Friday $2{ }^{\text {st }}$ September, 2007 Un Headquarters, New York.

Azubuike, I. (2006). Oil sector's sloppy accounts. Abuja Punch Magazine, 16.

Azubuike, J. U. B. (2009). Challenges of Tax Authorities, Tax payers in the management of Tax reform processes. Lagos, the Nigerian Institute of Chartered accountant of Nigeria. The Nigerian Accountant, 42(2), 41.

Bariyima, D. K., \& Nuka, N. N. (2009). Selected aspects of Nigerian Taxes. Springfield Publishers reprinted by Mgbaa Commercial Enterprises mile 2 Diobu Port Harcourt. 
CBN Statistical Bulletin. (2012). Annual Report.

Edwards, S., \& Aoki, M. (1983). Export Boom and Dutch - Diseases a dynamic analysis. Resources and Energy, (3), 219-242. http://dx.doi.org/10.1016/0165-0572(83)90026-9

Ekpo, \& Egwaikhide, F. (1994). Export and Economics Growth in Nigeria: A reconsideration of the evidence. $J$. Economic Manag., 1(1), 100-115.

Gbadebo, O. O. (2008). Crude Oil and the Nigerian economic performance: Oil and gas business. Retrieved from http://www.ogbus.ru/eng/

Ogbonna, G. N. (2012). Petroleum income and Nigeria economy Empirical Evidence. Arabian journal of Business and Management Review (OMAN chapter), (9). http://dx.doi.org/10.12816/0002159

Okpe. (2003). Petroleum profit tax in Nigeria. Joebist Book Enugu.

Wilson, U. A., Ugbor, R., \& Igbeka, V. C. (2012). Petroleum profits and miscellaneous taxation in Nigeria. Immaculate publications Lt: Reprinted by EMC Publishers Ogui, Enugu.

\section{Appendix 1}

Total federal collected revenue, oil revenue and gross domestic product

\begin{tabular}{cccc}
\hline YEARS & TFCR & OR & GDP \\
\hline 1991 & $100,991.60$ & $82,666.40$ & $312,139.74$ \\
1992 & $190,453.20$ & 164078.10 & $532,613.83$ \\
1993 & 192769.40 & 162102.40 & 683869.79 \\
1994 & 201910.80 & 160192.40 & 899863.22 \\
1995 & 459987.30 & 324547.60 & $1,933,211.55$ \\
1996 & 523597.00 & 408783.00 & $2,702719.13$ \\
1997 & 582811.10 & 416811.10 & 2801972.58 \\
1998 & 463668.80 & 324311.20 & 2708430.86 \\
1999 & 949187.90 & 724422.50 & $3,194014.97$ \\
2000 & 949187.90 & $1,591675.80$ & 4582127.29 \\
2001 & 1906159.70 & 1707562.80 & 4725086.00 \\
2002 & 22316000.00 & 1230851.20 & $6,912381.25$ \\
2003 & $1,731837.50$ & $2,074280.60$ & $8,487031.57$ \\
2004 & 2575095.90 & 2974880.00 & 1147106.91 \\
2005 & $3,9220500.00$ & 3894165.60 & $1,4572,239.15$ \\
2006 & $5,965101.00$ & 47266.80 & $1,8564,804.56$ \\
2007 & $5,715500.00$ & 5552770.20 & 20657317.67 \\
2008 & $7,866590.38$ & $6,530600.00$ & 24296329.29 \\
2009 & $4,8445925.42$ & 3191900.00 & 24794238.66 \\
2010 & $7,3036671.55$ & 5396100.00 & 33984754.13 \\
2011 & 11116900.00 & 88790000.00 & $37,409860.61$ \\
2012 & 10657724.84 & 8025953.48 & 40544099.94 \\
\hline
\end{tabular}

Source: CBN Statistical Bulletin 2012.

\section{Appendix 2}

\section{Computations of growth rates in TFCR, or and GDP}

\begin{tabular}{cccc}
\hline YEARS & GTFCR & GOR $(\mathbf{M})$ & GGDP $(\mathbf{M})$ \\
\hline 1992 & $88.58 \%$ & $9.84 \%$ & $70.63 \%$ \\
1993 & $1.21 \%$ & $-1.20 \%$ & $28.39 \%$ \\
1994 & $4.74 \%$ & $-1.17 \%$ & $31.58 \%$ \\
1995 & $127.81 \%$ & $102.59 \%$ & $114.83 \%$ \\
1996 & $13.82 \%$ & $25.95 \%$ & $39.80 \%$ \\
1997 & $11.30 \%$ & $.12969 \%$ & $3.67 \%$ \\
1998 & $-20.45 \%$ & $-22.19 \%$ & $-3.33 \%$ \\
1999 & $104.73 \%$ & $123.37 \%$ & $17.92 \%$ \\
\hline
\end{tabular}




\begin{tabular}{cccc}
\hline 2000 & $100.82 \%$ & $119.71 \%$ & $43.45 \%$ \\
2001 & $17.07 \%$ & $72,80 \%$ & $3.11 \%$ \\
2002 & $-22.39 \%$ & $\%-27,91$ & $46.29 \%$ \\
2003 & $48.69 \%$ & $68.52 \%$ & $22.78 \%$ \\
2004 & $52.24 \%$ & $73.16 \%$ & $-86.53 \%$ \\
2005 & $11.49 \%$ & $120.90 \%$ & $1.177 .02 \%$ \\
2006 & $7.52 \%$ & $4.58 \%$ & $27.39 \%$ \\
2007 & $-4.18 \%$ & $36.34 \%$ & $11.279 \%$ \\
2008 & $37.63 \%$ & $17.60 \%$ & $17.61 \%$ \\
2009 & $-38.41 \%$ & $-51.12 \%$ & $2.04 \%$ \\
2010 & $50.75 \%$ & $69.05 \%$ & $37.06 \%$ \\
2011 & $5.22 \%$ & $64.54 \%$ & $10.07 \%$ \\
2012 & $-4.15 \%$ & $-9.60 \%$ & $8.37 \%$ \\
\hline
\end{tabular}

Source: Researchers estimation, 2015.

\section{Copyrights}

Copyright for this article is retained by the author(s), with first publication rights granted to the journal.

This is an open-access article distributed under the terms and conditions of the Creative Commons Attribution license (http://creativecommons.org/licenses/by/3.0/). 